\title{
Stimulation of Suicidal Erythrocyte Death by PRIMA-1
}

\author{
Caterina Faggio ${ }^{a} \quad$ Kousi Alzoubib ${ }^{b}$ Salvatrice Calabròa, Florian Lang $^{\mathrm{b}}$
}

aDepartment of Biological and Environmental Sciences, University of Messina, Agata-Messina, Italy;

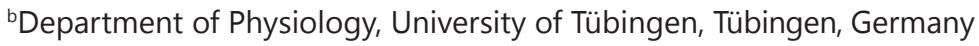

\section{Key Words}

Phosphatidylserine $\cdot$ PRIMA-1 $・$ Calcium $・$ Ceramide $・$ Eryptosis

\begin{abstract}
Background: The anticarcinogenic drug PRIMA-1 ( $\mathrm{p} 53$ reactivation and induction of massive apoptosis 1) induces suicidal death of tumor cells, an effect in large part attributed to the up-regulation of the proapoptotic transcription factor p53. Erythrocytes are lacking gene transcription but are nevertheless able to enter eryptosis, a suicidal erythrocyte death characterized by cell shrinkage and cell membrane scrambling with phosphatidylserine translocation to the erythrocyte surface. Stimulators of eryptosis include increase of cytosolic $\mathrm{Ca}^{2+}$-activity $\left(\left[\mathrm{Ca}^{2+}\right]_{\mathrm{i}}\right)$ and ceramide formation. The present study tested whether PRIMA-1 stimulates eryptosis. Methods: Phosphatidylserine exposure at the cell surface was estimated from annexin $\mathrm{V}$ binding, cell volume from forward scatter, $\left[\mathrm{Ca}^{2+}\right]_{i}$ from Fluo3-fluorescence, ceramide abundance from binding of specific antibodies, and ROS formation from DCFDA fluorescence. Results: A 48 h exposure of human erythrocytes to PRIMA-1 (25 $\mu \mathrm{M})$ significantly increased the percentage of annexin-V-binding cells without significantly influencing $\left[\mathrm{Ca}^{2+}\right]_{i}$ or forward scatter. PRIMA-1 $(100 \mu \mathrm{M})$ induced annexin-V-binding was not significantly blunted by removal of extracellular $\mathrm{Ca}^{2+}$ or by the caspase-3 inhibitor zVAD. PRIMA-1 (100 $\left.\mu \mathrm{M}\right)$ further increased the ceramide abundance at the cell surface and ROS formation. Conclusions: PRIMA-1 stimulates phosphatidylserine translocation at the erythrocyte cell membrane, an effect at least partially due to up-regulation of ceramide abundance and ROS formation.
\end{abstract}




\section{Introduction}

PRIMA-1 (p53 reactivation and induction of massive apoptosis 1 or APR-246), a widely used investigational drug for cancer therapy successfully tested in phase I/II clinical trials [1-3], triggers apoptosis of tumor cells and augments the tumor cell apoptosis following cytostatic treatment, radiation or hypoxia [1, 3-29]. The substance is at least partially effective by reactivating the proapoptotic transcription factor p53 [1, 3-5, 7, 8, 11-14, 16, 18 $21,23,25-27,30]$. Moreover, PRIMA-1 up-regulates the related transcription factors p63 and p73 [2, 26]. PRIMA-1 may further stimulate autophagy [31]. In addition, PRIMA-1 derivatives have been shown to stimulate ceramide formation [32].

Erythrocytes lack nuclei and are unable to execute transcription factor dependent gene expression. Nevertheless, erythrocytes may enter suicidal cell death or eryptosis, which is characterized by cell shrinkage [33] and cell membrane scrambling with exposure of phosphatidylserine at the cell surface [34]. Signaling involved in the stimulation of eryptosis includes increase of cytosolic $\mathrm{Ca}^{2+}$ activity $\left(\left[\mathrm{Ca}^{2+}\right]_{\mathrm{i}}\right)$ [34], formation of ceramide [35], oxidative stress [36], caspase activation [37-41], activation of casein kinase $1 \alpha[42,43]$, Janus-activated kinase JAK3 [44], protein kinase C [45], or p38 kinase [46], as well as inhibition or knockout of AMP activated kinase AMPK [47], cGMP-dependent protein kinase [38], PAK2 kinase [48], sorafenib sensitive kinases [49] and sunitinib sensitive kinases [50].

The present study tested, whether PRIMA- 1 is able to stimulate eryptosis. To this end, phosphatidylserine surface abundance, cell volume, $\left[\mathrm{Ca}^{2+}\right]_{i}$, ceramide abundance, and ROS formation were determined in human erythrocytes from healthy individuals prior to and following treatment with PRIMA-1.

\section{Materials and Methods}

\section{Ethics statement}

All experiments in this manuscript have been approved by the appropriate ethics committee and have therefore been performed in accordance with the ethical standards laid down in the 1964 Declaration of Helsinki. The study is approved by the ethics committee of the University of Tübingen (184/2003 V).

Erythrocytes, solutions and chemicals

Fresh Lithium-Heparin-anticoagulated blood samples were kindly provided by the blood bank of the University of Tübingen. The blood was centrifuged at $120 \mathrm{rcf}$ for $20 \mathrm{~min}$ at $23^{\circ} \mathrm{C}$ and the platelets and leukocytescontaining supernatant was disposed. Erythrocytes were incubated in vitro at a hematocrit of $0.4 \%$ in Ringer solution containing (in $\mathrm{mM}$ ) $125 \mathrm{NaCl}, 5 \mathrm{KCl}, 1 \mathrm{MgSO}_{4}, 32 \mathrm{~N}$-2-hydroxyethylpiperazine-N-2-ethanesulfonic acid (HEPES), 5 glucose, $1 \mathrm{CaCl}_{2}$; $\mathrm{pH} 7.4$ at $37^{\circ} \mathrm{C}$ for $48 \mathrm{~h}$. Where indicated, erythrocytes were exposed to PRIMA-1 (Sigma Aldrich, Schnelldorf, Germany) at the indicated concentrations, whereby 5 mg PRIMA-1 were solved in $270 \mathrm{\mu l} \mathrm{H}_{2} \mathrm{O}$ to yield a $100 \mathrm{mM}$ stock solution.

\section{Analysis of annexin-V-binding and forward scatter}

After incubation under the respective experimental condition, $50 \mu \mathrm{l}$ cell suspension was washed in Ringer solution containing $5 \mathrm{mM} \mathrm{CaCl}_{2}$ and then stained with Annexin-V-FITC (1:200 dilution; ImmunoTools, Friesoythe, Germany) in this solution at $37^{\circ} \mathrm{C}$ for $20 \mathrm{~min}$ under protection from light. In the following, the forward scatter (FSC) of the cells was determined, and annexin-V-FITC fluorescence intensity was measured with an excitation wavelength of $488 \mathrm{~nm}$ and an emission wavelength of $530 \mathrm{~nm}$ on a FACS Calibur (BD, Heidelberg, Germany).

\section{Measurement of intracellular $\mathrm{Ca}^{2+}$}

After incubation, erythrocytes were washed in Ringer solution and then loaded with Fluo-3/AM (Biotium, Hayward, USA) in Ringer solution containing $5 \mathrm{mM} \mathrm{CaCl}_{2}$ and $5 \mu \mathrm{M}$ Fluo-3/AM. The cells were incubated at $37^{\circ} \mathrm{C}$ for $30 \mathrm{~min}$ and washed twice in Ringer solution containing $5 \mathrm{mM} \mathrm{CaCl}_{2}$. The Fluo-3/ AM-loaded erythrocytes were resuspended in $200 \mu$ Ringer. Then, $\mathrm{Ca}^{2+}$-dependent fluorescence intensity 
Faggio/Alzoubi/Calabrò/Lang: PRIMA-1-Induced Eryptosis

was measured with an excitation wavelength of $488 \mathrm{~nm}$ and an emission wavelength of $530 \mathrm{~nm}$ on a FACS Calibur.

\section{Determination of ceramide formation}

To determine ceramide abundance, a monoclonal antibody-based assay was used. After incubation, cells were stained for $1 \mathrm{~h}$ at $37^{\circ} \mathrm{C}$ with $1 \mu \mathrm{g} / \mathrm{ml}$ anti-ceramide antibody (clone MID 15B4; Alexis, Grünberg, Germany) in phosphate-buffered saline (PBS) containing $0.1 \%$ bovine serum albumin (BSA) at a dilution of 1:10. After two washing steps with PBS-BSA, cells were stained for $30 \mathrm{~min}$ with polyclonal fluoresceinisothiocyanate (FITC)-conjugated goat anti-mouse IgG and IgM specific antibody (Pharmingen, Hamburg, Germany) diluted 1:50 in PBS-BSA. Unbound secondary antibody was removed by repeated washing with PBS-BSA. Samples were then analyzed by flow cytometric analysis at an excitation wavelength of $488 \mathrm{~nm}$ and an emission wavelength of $530 \mathrm{~nm}$.

Quantification of reactive oxidant species (ROS)

Oxidative stress was determined utilizing 2',7'-dichlorodihydrofluorescein diacetate (DCFDA). After incubation, a $50 \mu \mathrm{l}$ suspension of erythrocytes was washed in Ringer solution and then stained with DCFDA (Sigma, Schnelldorf, Germany) in Ringer solution containing DCFDA at a final concentration of 10 $\mu \mathrm{M}$. Erythrocytes were incubated at $37^{\circ} \mathrm{C}$ for $30 \mathrm{~min}$ in the dark and then washed three times in Ringer solution. The DCFDA-loaded erythrocytes were resuspended in $200 \mu$ l Ringer solution, and ROS-dependent fluorescence intensity was measured at an excitation wavelength of $488 \mathrm{~nm}$ and an emission wavelength of $530 \mathrm{~nm}$ on a FACS Calibur (BD).

\section{Statistics}

Data are expressed as arithmetic means \pm SEM. As indicated in the figure legends, statistical analysis was made using ANOVA with Tukey's test as post-test and $t$ test as appropriate. $\mathrm{n}$ denotes the number of different erythrocyte specimens studied. Since different erythrocyte specimens used in distinct experiments are differently susceptible to triggers of eryptosis, the same erythrocyte specimens have been used for control and experimental conditions.

\section{Results}

The present study explored whether PRIMA-1 was capable to induce eryptosis, the suicidal erythrocyte death. The decisive hallmark of eryptosis is phospholipid scrambling of the cell membrane with phosphatidylserine translocation to the cell surface.

In order to identify phosphatidylserine exposing erythrocytes, binding of labeled Annexin-V was determined utilizing flow cytometry. The measurements were performed following incubation of erythrocytes for 48 hours in Ringer solution without or with presence of PRIMA-1 $(10-100 \mu \mathrm{M})$ prior to the measurements. As illustrated in Fig. 1, a $48 \mathrm{~h}$ exposure to PRIMA-1 enhanced the percentage of annexin-V-binding erythrocytes, an effect reaching statistical significance at $25 \mu$ M PRIMA-1. PRIMA-1 treatment thus resulted in erythrocyte cell membrane scrambling with subsequent translocation of phosphatidylserine to the cell surface. An extended dose response curve is provided in Fig.1C,D. Calculation of an EC50 from log[agonist] vs. normalized response (variable slope) utilizing Graphpad Prism software yielded a value of $3.5 \mathrm{mM}$. In a separate series, the percentage of Annexin-V binding erythrocytes was significantly $(\mathrm{p}<0.05)$ lower when $100 \mu$ M PRIMA-1 was added for 24 hours and the erythrocytes were subsequently exposed for additional 24 hours without PRIMA-1 $(3.0 \pm 0.5 \%, \mathrm{n}=8)$ than when PRIMA- 1 was added for 48 hours $(5.0 \pm 0.7 \%, \mathrm{n}=8)$.

Alterations of cell volume were evidenced by alterations of forward scatter, which was again determined in flow cytometry. Forward scatter was quantified after incubation of the erythrocytes for $48 \mathrm{~h}$ in Ringer solution without or with PRIMA-1 (10 - $100 \mu \mathrm{M})$. As illustrated in Fig. 2, incubation of human erythrocytes in Ringer solution with PRIMA-1 tended to slightly decrease forward scatter, an effect, however, not reaching statistical significance.

\section{KARGER}


Fig. 1. Effect of PRIMA-1 on phosphatidylserine exposure. A. Original histogram of annexin-V-binding of erythrocytes (M1) following exposure for 48 $\mathrm{h}$ to Ringer solution without (grey area) and with (black line) presence of 100 $\mu \mathrm{M}$ PRIMA-1. B. Arithmetic means \pm SEM of erythrocyte annexin-V-binding ( $\mathrm{n}=20$ ) following incubation for $48 \mathrm{~h}$ to Ring-

A

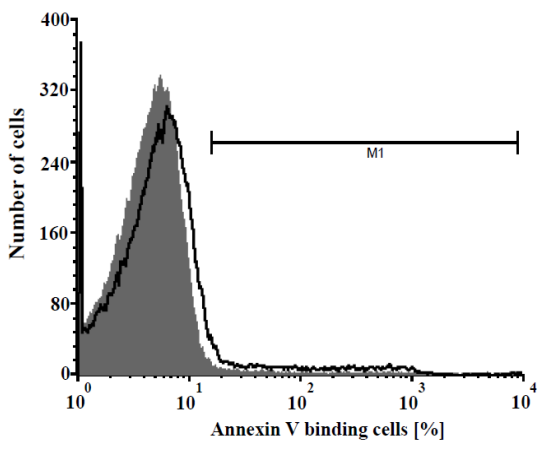

C

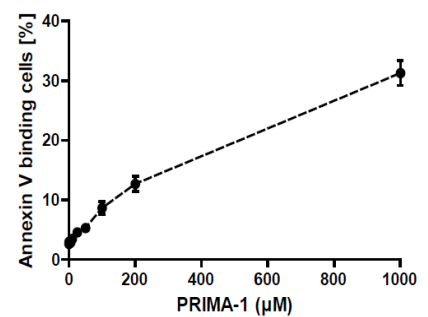

B

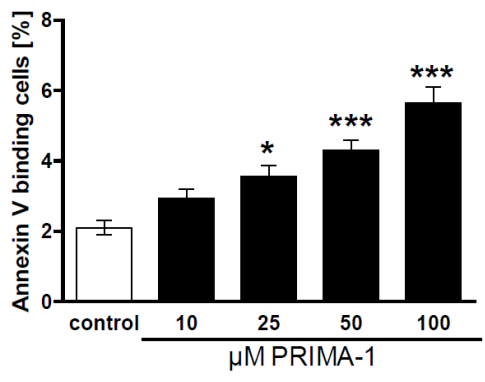

D

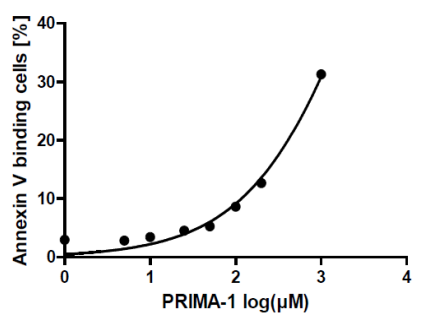
er solution without (white bar) or with (black bars) presence of PRIMA-1 $(10-100 \mu \mathrm{M}) .{ }^{*}(\mathrm{p}<0.05),{ }^{* * *}(\mathrm{p}<0.001)$, indicates significant difference from the absence of PRIMA-1 (ANOVA). C,D. The percentage of erythrocytes binding annexin- $V$ as a linear (C) and semilogarithmic (D) function of PRIMA-1 concentration ( $n=8)$.

A

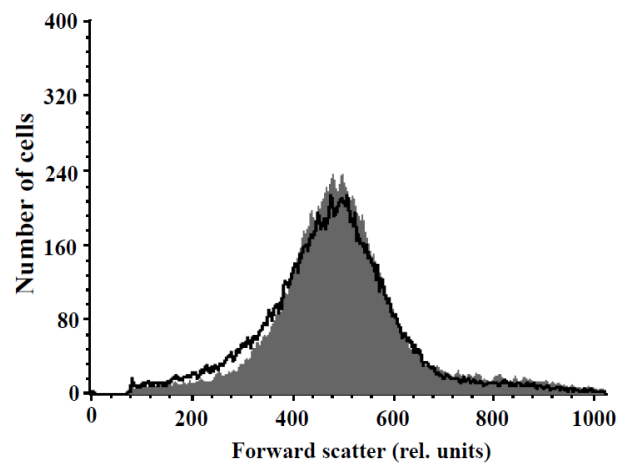

B

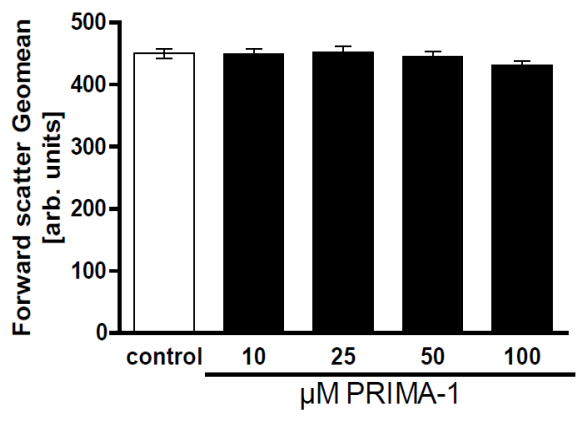

Fig. 2. Effect of PRIMA-1 on erythrocyte forward scatter. A. Original histogram of forward scatter of erythrocytes following exposure for $48 \mathrm{~h}$ to Ringer solution without (grey area) and with (black line) presence of $100 \mu \mathrm{M}$ PRIMA-1. B. Arithmetic means \pm SEM $(\mathrm{n}=20)$ of the normalized erythrocyte forward scatter (FSC) following incubation for $48 \mathrm{~h}$ to Ringer solution without (white bar) or with (black bars) presence of PRIMA-1 $(10-100 \mu \mathrm{M})$. No significant differences were observed (ANOVA).

Alterations of cytosolic $\mathrm{Ca}^{2+}$ activity $\left(\left[\mathrm{Ca}^{2+}\right]_{\mathrm{i}}\right)$ were estimated utilizing Fluo3 fluorescence, which was again determined in flow cytometry. As shown in Fig. 3A,B, a $48 \mathrm{~h}$ exposure to PRIMA-1 $(10-100 \mu \mathrm{M})$ did not significantly modify Fluo3 fluorescence, indicating that PRIMA-1 did not alter appreciably $\left[\mathrm{Ca}^{2+}\right]_{i}$. Further experiments were performed to explore whether the PRIMA-1-induced cell membrane scrambling required entry of extracellular 


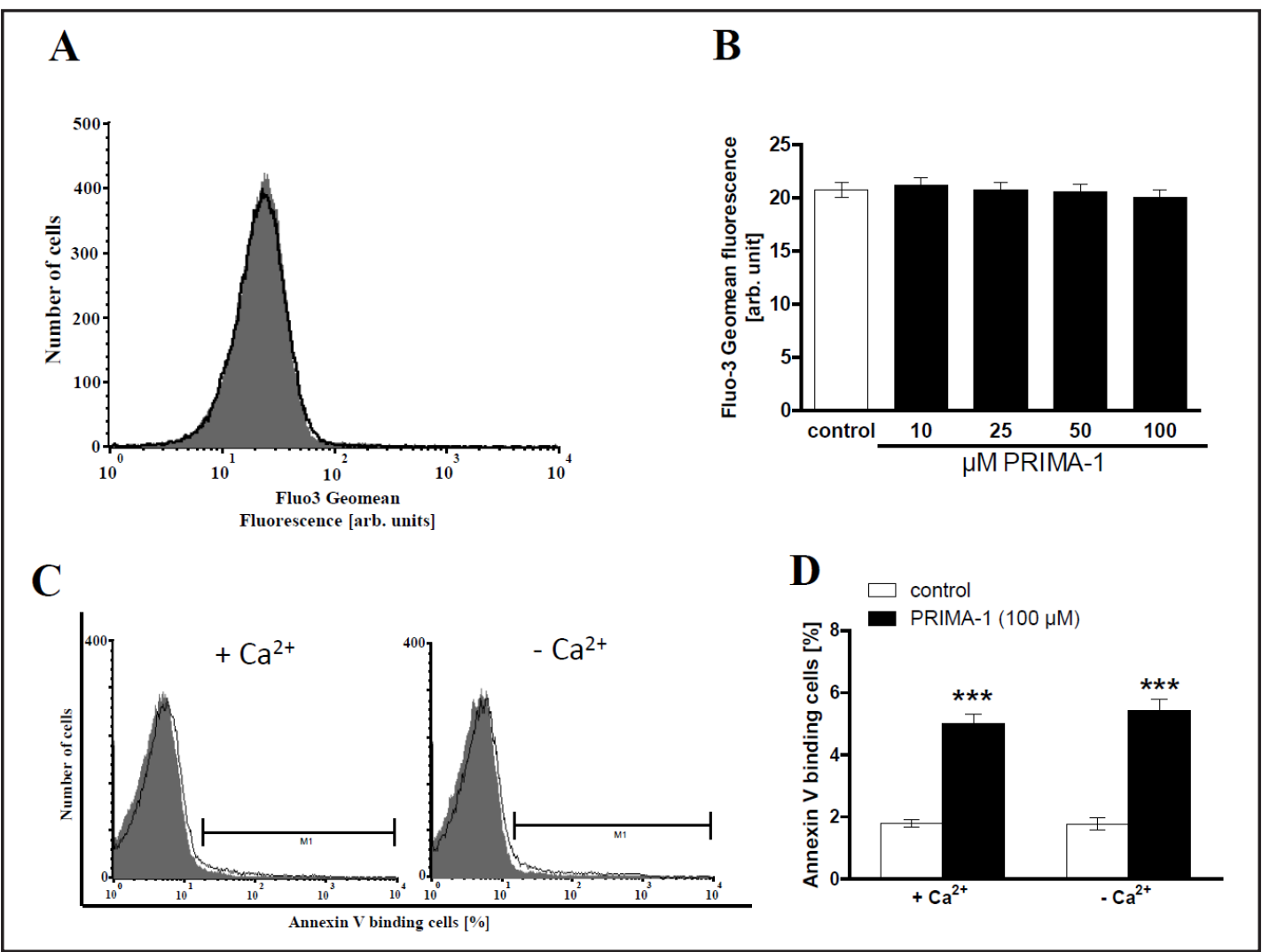

Fig. 3. Effect of PRIMA-1 on erythrocyte $\mathrm{Ca}^{2+}$ activity and $\mathrm{Ca}^{2+}$ dependence of PRIMA-1- induced phosphatidylserine exposure. A. Original histogram of Fluo3 fluorescence in erythrocytes following exposure for 48 $\mathrm{h}$ to Ringer solution without (grey area) and with (black line) presence of $100 \mu \mathrm{M}$ PRIMA-1. B. Arithmetic means \pm SEM $(n=20)$ of the Fluo3 fluorescence (arbitrary units) in erythrocytes exposed for $48 \mathrm{~h}$ to Ringer solution without (white bar) or with (black bars) presence of PRIMA-1 (10 - $100 \mu \mathrm{M})$. No significant differences were observed (ANOVA). C. Original histograms of annexin-V-binding of erythrocytes following exposure for $48 \mathrm{~h}$ to Ringer solution in the prescense (left) or absence (right) of calcium, without (grey area) and with (black line) presence of $100 \mu$ M PRIMA-1. D. Arithmetic means \pm SEM $(n=8)$ of erythrocyte forward scatter after a $48 \mathrm{~h}$ treatment with Ringer solution without (white bars) or with (black bars) $100 \mu \mathrm{M}$ PRIMA-1 in the presence (left bars, $\left.+\mathrm{Ca}^{2+}\right)$ and absence (right bars, $\left.-\mathrm{Ca}^{2+}\right)$ of calcium. ${ }^{* * *}(\mathrm{p}<0.001)$ indicates significant difference from the absence of PRIMA-1.

Fig. 4. PRIMA-1- induced annexin-V-bindingin presence of caspase inhibitor zVAD. Arithmetic means \pm SEM $(n=8)$ of the percentage of annexin-V-binding erythrocytes after a $48 \mathrm{~h}$ treatment with Ringer solution without (white bars) or with (black bars) 100 $\mu \mathrm{M}$ PRIMA-1 in the absence (left bars) and presence (right bars) of caspase inhibitor zVAD $(10 \mu \mathrm{M})$. *** $(\mathrm{p}<0.001)$ indicates significant difference from the absence of PRIMA-1 (ANOVA).

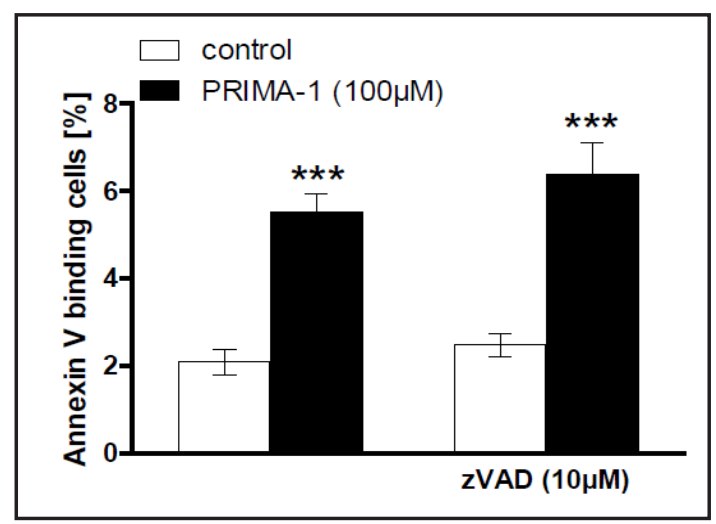

$\mathrm{Ca}^{2+}$. To this end, the erythrocytes were exposed for $48 \mathrm{~h}$ to $100 \mu \mathrm{M}$ PRIMA-1 in the presence or nominal absence of extracellular $\mathrm{Ca}^{2+}$. As shown in Fig. 3C, removal of extracellular $\mathrm{Ca}^{2+}$ did not significantly affect the increase of annexin-V-binding following PRIMA-1 treatment. 
A

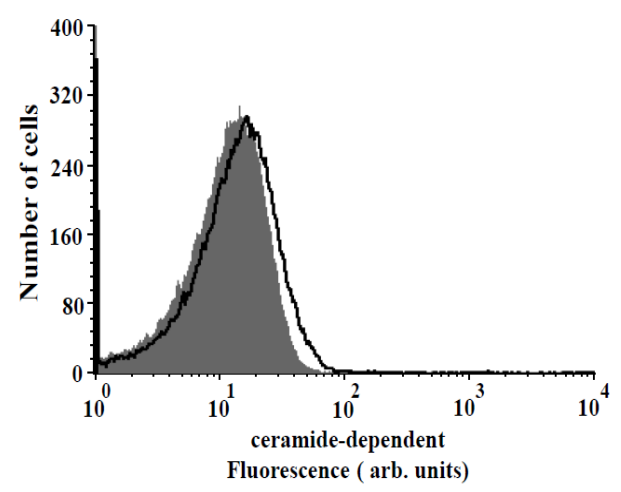

\section{B}

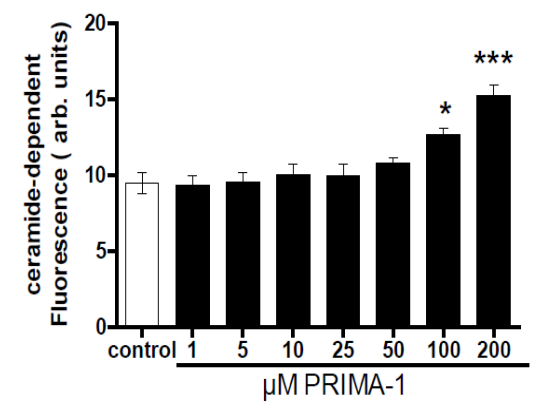

Fig. 5. Effect of PRIMA-1 on ceramide formation. A. Original histogram of ceramide surface abundance of erythrocytes following exposure for $48 \mathrm{~h}$ to Ringer solution without (grey shadow) and with (black line) presence of $100 \mu$ M PRIMA-1. B. Arithmetic means \pm SEM $(n=8)$ of ceramide abundance after a $48 \mathrm{~h}$ incubation in Ringer solution without (white bar) or with (black bars) $1-200 \mu$ M PRIMA-1. ${ }^{*}(\mathrm{p}<0.05),{ }^{* * *}(\mathrm{p}<0.001)$ indicates significant difference from the absence of PRIMA-1 (ANOVA).
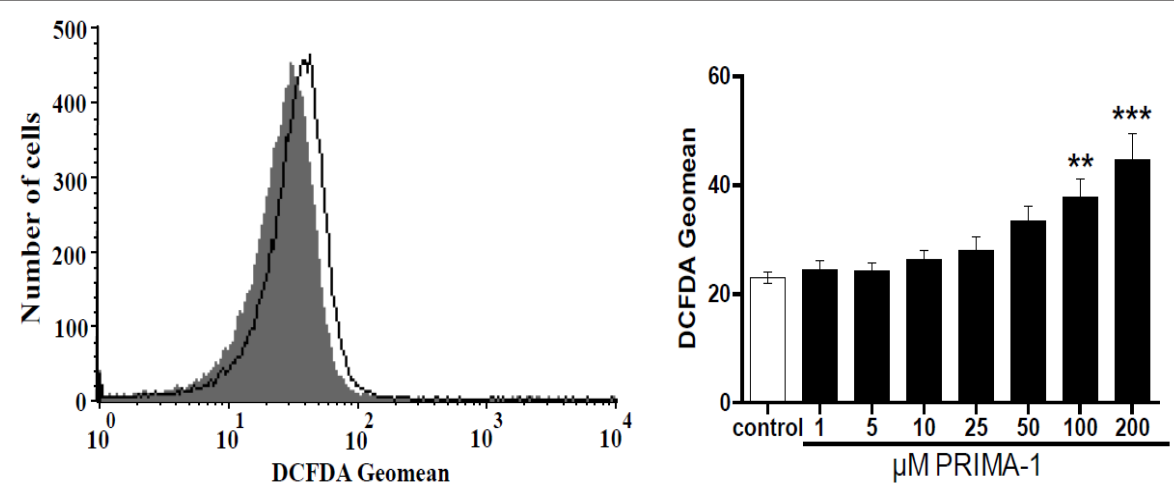

Fig. 6. Effect of PRIMA-1 on reactive oxygen species. A. Original histogram of $2^{\prime}, 7^{\prime}$-dichlorodihydrofluorescein diacetate (DCFDA) fluorescence in erythrocytes following exposure for 48 hours to Ringer solution without (grey shadow) and with (black line) presence of $100 \mu \mathrm{M}$ PRIMA-1. B. Arithmetic means \pm SEM ( $\mathrm{n}=$ 8) of erythrocyte DCFDA fluorescence following incubation for 48 hours to Ringer solution without (white bar) or with (black bar) presence of PRIMA-1 $(1-200 \mu \mathrm{M}) .{ }^{* *}(\mathrm{p}<0.01),{ }^{* * *}(\mathrm{p}<0.001)$ indicates significant difference from the absence of PRIMA-1 (ANOVA).

Instead, PRIMA-1 significantly increased the percentage of annexin-V-binding erythrocytes even in the absence of extracellular $\mathrm{Ca}^{2+}$. Thus, the effect of PRIMA-1 on phosphatidylserine translocation was mediated by a mechanism other than entry of extracellular $\mathrm{Ca}^{2+}$.

A further series of experiments addressed the putative involvement of caspases. To this end, erythrocytes were exposed to $100 \mu \mathrm{M}$ PRIMA-1 for $48 \mathrm{~h}$ either in the absence or presence of the pancaspase inhibitor zVAD (1 or $10 \mu \mathrm{M})$. As illustrated in Figure 4, zVAD did not significantly modify the effect of PRIMA-1 on annexin $V$ binding.

As cell membrane scrambling could be triggered without requirement of increased $\left[\mathrm{Ca}^{2+}\right]_{\mathrm{i}}$ by ceramide, a further series of experiments explored, whether PRIMA-1-induced cell membrane scrambling was paralleled by formation of ceramide. To this end, the ceramide abundance at the erythrocyte surface was determined utilizing a specific anti-ceramide antibody. As shown in Fig. 5, a 48 h exposure of erythrocytes to PRIMA-1 increased the abundance of ceramide at the erythrocyte surface, an effect reaching statistical significance at $100 \mu \mathrm{M}$. 
In order to test whether PRIMA-1 enhances oxidative stress, reactive oxygen species (ROS) were determined utilizing 2',7'-dichlorodihydrofluorescein diacetate (DCFDA), As illustrated in fig.6, a $48 \mathrm{~h}$ treatment with PRIMA-1 increased DCFDA fluorescence, an effect reaching statistical significance at $100 \mu \mathrm{M}$.

\section{Discussion}

The present study reveals that exposure of human erythrocytes to high PRIMA-1 concentrations is followed by stimulation of cell membrane scrambling with phosphatidylserine translocation and increase of ceramide abundance at the erythrocyte surface. Phosphatidylserine exposure at the cell surface is a hallmark of eryptosis, the suicidal death of erythrocytes [34].

The cell membrane scrambling following PRIMA-1 treatment was not paralleled by an increase of $\left[\mathrm{Ca}^{2+}\right]_{\mathrm{i}}$. Moreover, removal ef extracellular $\mathrm{Ca}^{2+}$ did not significantly modify the stimulation of eryptosis by PRIMA-1. Instead, PRIMA-1 triggered phosphatidylserine exposure even in the absence of extracellular $\mathrm{Ca}^{2+}$. Thus, PRIMA-1 was effective by mechanisms other than increase of $\left[\mathrm{Ca}^{2+}\right]_{\mathrm{i}}$. Moreover, the effect of PRIMA- 1 was not significantly modified by the caspase inhibitor zVAD and was thus not dependent on caspase activation. Instead PRIMA-1 stimulated the formation of ceramide, an effect well known to stimulate eryptosis [34]. PRIMA-1 derivatives have most recently been shown to stimulate ceramide formation in tumor cells [32]. Moreover, PRIMA-1 induced oxidative stress, a well known stimulator of erythrocyte cell membrane scrambling [34].

PRIMA-1 tended to decrease cell volume, an effect, however, not reaching statistical significance. Thus, PRIMA-1 failed to significantly trigger the second hallmark of eryptosis. Moreover, PRIMA-1 apparently did not trigger membrane blebbing with formation of small particles, a further hall mark of eryptosis. This observation parallels the lack of PRIMA-1 effect on $\left[\mathrm{Ca}^{2+}\right]_{i}$. Eryptotic cell shrinkage is usually caused by increase of $\left[\mathrm{Ca}^{2+}\right]_{\mathrm{i}}$ with subsequent activation of $\mathrm{Ca}^{2+}$ sensitive $\mathrm{K}^{+}$channels, $\mathrm{K}^{+}$exit, hyperpolarization of the cell membrane, $\mathrm{Cl}^{-}$ exit and thus cellular loss of $\mathrm{KCl}$ with osmotically obliged water [33]. The possibility must be kept in mind that PRIMA-1 triggers a programmed necrosis, a suicidal death distinct from eryptosis [51].

The PRIMA-1 concentration $(25 \mu \mathrm{M})$ required for statistically significant stimulation of erythrocyte cell membrane scrambling was higher than those triggering apoptosis in tumor cells $[12,16]$. PRIMA-1 tended to increase phosphatidylserine exposure at lower concentrations $(10 \mu \mathrm{M})$, an effect, however, not reaching statistical significance. It must be kept in mind that erythrocytes may be sensitized to the effect of PRIMA- 1 by other xenobiotics stimulating cell membrane scrambling $[35,49,50,52-82]$ or by diseases associated with enhanced cell membrane scrambling, such as sepsis, malaria, sickle cell disease, Wilson's disease, iron deficiency, malignancy, metabolic syndrome, diabetes, hepatic failure, renal insufficiency, hemolytic uremic syndrome, hyperphosphatemia and phosphate depletion [34, 83, 84].

The sensitization of erythrocytes for cell membrane scrambling by ceramide may, at least in theory, be relevant in malaria. The malaria pathogen Plasmodium triggers eryptosis by induction of oxidative stress, which activates several ion channels of the host cell membrane including $\mathrm{Ca}^{2+}$-permeable erythrocyte cation channels $[85,86]$. The $\mathrm{Ca}^{2+}$ entry through unselective cation channels triggers eryptosis with subsequent clearance of the infected erythrocytes from circulating blood [87]. Several genetic erythrocyte disorders including sickle-cell trait, beta-thalassemia-trait, homozygous $\mathrm{Hb}-\mathrm{C}$ and homozygous G6PD-deficiency enhance the susceptibility of erythrocytes for eryptosis and thus confer some protection against a severe course of malaria [34, 88-90]. Moreover, the clinical course of malaria is favourably influenced by clinical conditions with accelerated eryptosis, such as iron deficiency [91]. Eryptosis triggering xenobiotics shown to favourably influence the clinical course of malaria include lead [92], chlorpromazine [93] or NO synthase inhibitors [94]. Whether or not PRIMA-1 may influence the clinical course of malaria remains to be tested. 
On the other hand, eryptosis may lead to anemia due to phagocytosis and subsequent removal of phosphatidylserine exposing erythrocytes. Clinically overt anemia is observed as soon as the rate of eryptosis exceeds the formation of new erythrocytes [34]. The binding of phosphatidylserine exposing erythrocytes to endothelial CXCL16/SR-PSO may in addition lead to adherance of eryptotic erythrocytes to the vascular wall [95]. Phosphatidylserine exposing erythrocytes may further stimulate blood clotting and thrombosis [96-98]. As a result phosphatidylserine exposing erythrocytes may impair microcirculation [35, 96, 99$102]$.

In conclusion, PRIMA-1 stimulates erythrocyte cell membrane scrambling with phosphatidylserine translocation to the erythrocyte surface, an effect at least partially due to stimulation of ceramide formation.

\section{Disclosure Statement}

The authors declare that they have no conflict of interest.

\section{Acknowledgements}

The authors acknowledge the meticulous preparation of the manuscript by Tanja Loch. The study was supported by the Deutsche Forschungsgemeinschaft and the Open Access Publishing Fund of Tuebingen University.

\section{References}

1 Qiang W, Jin T, Yang Q, Liu W, Liu S, Ji M, He N, Chen C, Shi B, Hou P: PRIMA-1 selectively induces global DNA demethylation in p53 mutant-type thyroid cancer cells. J Biomed Nanotechnol 2014;10:1249-1258.

-2 Shen J, van den Bogaard EH, Kouwenhoven EN, Bykov VJ, Rinne T, Zhang Q, Tjabringa GS, Gilissen C, van Heeringen SJ, Schalkwijk J, van Bokhoven H, Wiman KG, Zhou H: APR-246/PRIMA-1(MET) rescues epidermal differentiation in skin keratinocytes derived from EEC syndrome patients with p63 mutations. Proc Natl Acad Sci U S A 2013;110:2157-2162.

3 Wang T, Lee K, Rehman A, Daoud SS: PRIMA-1 induces apoptosis by inhibiting JNK signaling but promoting the activation of Bax. Biochem Biophys Res Commun 2007;352:203-212.

-4 Aryee DN, Niedan S, Ban J, Schwentner R, Muehlbacher K, Kauer M, Kofler R, Kovar H: Variability in functional p53 reactivation by PRIMA-1(Met)/APR-246 in Ewing sarcoma. Br J Cancer 2013;109:26962704.

-5 Bykov VJ, Issaeva N, Selivanova G, Wiman KG: Mutant p53-dependent growth suppression distinguishes PRIMA-1 from known anticancer drugs: a statistical analysis of information in the National Cancer Institute database. Carcinogenesis 2002;23:2011-2018.

-6 Bykov VJ, Zache N, Stridh H, Westman J, Bergman J, Selivanova G, Wiman KG: PRIMA-1(MET) synergizes with cisplatin to induce tumor cell apoptosis. Oncogene 2005;24:3484-3491.

7 Bykov VJN, Issaeva B, Shilov A, Hultcrantz M, Pugacheva E, Chumakov P, Bergman J, Wiman KG, Selivanova G: Restoration of the tumor suppressor function to mutant $\mathrm{p} 53$ by a low molecular weight compund. Nat Med 1985;8:282-288.

8 Charlot JF, Nicolier M, Pretet JL, Mougin C: Modulation of p53 transcriptional activity by PRIMA-1 and Pifithrin-alpha on staurosporine-induced apoptosis of wild-type and mutated p53 epithelial cells. Apoptosis 2006;11:813-827.

9 Cory AH, Chen J, Cory JG: Effects of PRIMA-1 on wild-type L1210 cells expressing mutant p53 and drugresistant L1210 cells lacking expression of p53: necrosis vs. apoptosis. Anticancer Res 2006;26:1289-1295.

10 Duan W, Gao L, Wu X, Wang L, Nana-Sinkam SP, Otterson GA, Villalona-Calero MA: MicroRNA-34a is an important component of PRIMA-1-induced apoptotic network in human lung cancer cells. Int J Cancer 2010;127:313-320. 
Faggio/Alzoubi/Calabrò/Lang: PRIMA-1-Induced Eryptosis

11 Izetti P, Hautefeuille A, Abujamra AL, de Farias CB, Giacomazzi J, Alemar B, Lenz G, Roesler R, Schwartsmann G, Osvaldt AB, Hainaut P, Ashton-Prolla P: PRIMA-1, a mutant p53 reactivator, induces apoptosis and enhances chemotherapeutic cytotoxicity in pancreatic cancer cell lines. Invest New Drugs 2014;10.1007/s10637-014-0090-9

12 Kobayashi N, Abedini M, Sakuragi N, Tsang BK: PRIMA-1 increases cisplatin sensitivity in chemoresistant ovarian cancer cells with p53 mutation: a requirement for Akt down-regulation. J Ovarian Res 2013;6:7.

13 Lambert JM, Gorzov P, Veprintsev DB, Soderqvist M, Segerback D, Bergman J, Fersht AR, Hainaut P, Wiman KG, Bykov VJ: PRIMA-1 reactivates mutant p53 by covalent binding to the core domain. Cancer Cell 2009;15:376-388.

14 Lee K, Wang T, Paszczynski AJ, Daoud SS: Expression proteomics to p53 mutation reactivation with PRIMA-1 in breast cancer cells. Biochem Biophys Res Commun 2006;349:1117-1124.

15 Li Y, Mao Y, Brandt-Rauf PW, Williams AC, Fine RL: Selective induction of apoptosis in mutant p53 premalignant and malignant cancer cells by PRIMA-1 through the c-Jun-NH2-kinase pathway. Mol Cancer Ther 2005;4:901-909.

16 Liang Y, Besch-Williford C, Hyder SM: PRIMA-1 inhibits growth of breast cancer cells by re-activating mutant p53 protein. Int J Oncol 2009;35:1015-1023.

17 Magrini R, Russo D, Ottaggio L, Fronza G, Inga A, Menichini P: PRIMA-1 synergizes with adriamycin to induce cell death in non-small cell lung cancer cells. J Cell Biochem 2008;104:2363-2373.

18 Messina RL, Sanfilippo M, Vella V, Pandini G, Vigneri P, Nicolosi ML, Giani F, Vigneri R, Frasca F: Reactivation of p53 mutants by prima-1 [corrected] in thyroid cancer cells. Int J Cancer 2012;130:2259-2270.

19 Nahi H, Lehmann S, Mollgard L, Bengtzen S, Selivanova G, Wiman KG, Paul C, Merup M: Effects of PRIMA-1 on chronic lymphocytic leukaemia cells with and without hemizygous p53 deletion. Br J Haematol 2004;127:285-291.

-20 Nahi H, Merup M, Lehmann S, Bengtzen S, Mollgard L, Selivanova G, Wiman KG, Paul C: PRIMA-1 induces apoptosis in acute myeloid leukaemia cells with p53 gene deletion. Br J Haematol 2006;132:230-236.

21 Piantino CB, Reis ST, Viana NI, Silva IA, Morais DR, Antunes AA, Dip N, Srougi M, Leite KR: Prima-1 induces apoptosis in bladder cancer cell lines by activating p53. Clinics (Sao Paulo) 2013;68:297-303.

-22 Rao CV, Patlolla JM, Qian L, Zhang Y, Brewer M, Mohammed A, Desai D, Amin S, Lightfoot S, Kopelovich L: Chemopreventive effects of the p53-modulating agents CP-31398 and Prima-1 in tobacco carcinogeninduced lung tumorigenesis in A/J mice. Neoplasia 2013;15:1018-1027.

23 Rehman A, Chahal MS, Tang X, Bruce JE, Pommier Y, Daoud SS: Proteomic identification of heat shock protein 90 as a candidate target for p53 mutation reactivation by PRIMA-1 in breast cancer cells. Breast Cancer Res 2005;7:R765-774.

24 Rieber M, Strasberg-Rieber M: Hypoxia, Mn-SOD and H(2)O(2) regulate p53 reactivation and PRIMA-1 toxicity irrespective of p53 status in human breast cancer cells. Biochem Pharmacol 2012;84:1563-1570.

25 Rokaeus N, Klein G, Wiman KG, Szekely L, Mattsson K: PRIMA-1(MET) induces nucleolar accumulation of mutant p53 and PML nuclear body-associated proteins. Oncogene 2007;26:982-992.

26 Rokaeus N, Shen J, Eckhardt I, Bykov VJ, Wiman KG, Wilhelm MT: PRIMA-1(MET)/APR-246 targets mutant forms of p53 family members p63 and p73. Oncogene 2010;29:6442-6451.

27 Russo D, Ottaggio L, Penna I, Foggetti G, Fronza G, Inga A, Menichini P: PRIMA-1 cytotoxicity correlates with nucleolar localization and degradation of mutant p53 in breast cancer cells. Biochem Biophys Res Commun 2010;402:345-350.

-28 Shi H, Lambert JM, Hautefeuille A, Bykov VJ, Wiman KG, Hainaut P, Caron de Fromentel C: In vitro and in vivo cytotoxic effects of PRIMA-1 on hepatocellular carcinoma cells expressing mutant p53ser249. Carcinogenesis 2008;29:1428-1434.

29 Supiot S, Zhao H, Wiman K, Hill RP, Bristow RG: PRIMA-1(met) radiosensitizes prostate cancer cells independent of their MTp53-status. Radiother Oncol 2008;86:407-411.

-30 Cui B, Yang Q Guan H, Shi B, Hou P, Ji M: PRIMA-1, a mutant p53 reactivator, restores the sensitivity of TP53 mutant-type thyroid cancer cells to the histone methylation inhibitor 3-Deazaneplanocin A. J Clin Endocrinol Metab 2014;99:E962-970.

-31 Russo D, Ottaggio L, Foggetti G, Masini M, Masiello P, Fronza G, Menichini P: PRIMA-1 induces autophagy in cancer cells carrying mutant or wild type p53. Biochim Biophys Acta 2013;1833:1904-1913.

32 Soans E, Evans SC, Cipolla C, Fernandes E: Characterizing the sphingomyelinase pathway triggered by PRIMA-1 derivatives in lung cancer cells with differing p53 status. Anticancer Res 2014;34:3271-3283. 
Faggio/Alzoubi/Calabrò/Lang: PRIMA-1-Induced Eryptosis

33 Lang PA, Kaiser S, Myssina S, Wieder T, Lang F, Huber SM: Role of Ca2+-activated K+ channels in human erythrocyte apoptosis. Am J Physiol Cell Physiol 2003;285:C1553-C1560.

-34 Lang E, Qadri SM, Lang F: Killing me softly - suicidal erythrocyte death. Int J Biochem Cell Biol 2012;44:1236-1243.

-35 Abed M, Towhid ST, Mia S, Pakladok T, Alesutan I, Borst O, Gawaz M, Gulbins E, Lang F: Sphingomyelinaseinduced adhesion of eryptotic erythrocytes to endothelial cells. Am J Physiol Cell Physiol 2012;303:C991999.

-36 Tesoriere L, Attanzio A, Allegra M, Cilla A, Gentile C, Livrea MA: Oxysterol mixture in hypercholesterolemiarelevant proportion causes oxidative stress-dependent eryptosis. Cell Physiol Biochem 2014;34:10751089.

-37 Bhavsar SK, Bobbala D, Xuan NT, Foller M, Lang F: Stimulation of suicidal erythrocyte death by alpha-lipoic acid. Cell Physiol Biochem 2010;26:859-868.

-38 Foller M, Feil S, Ghoreschi K, Koka S, Gerling A, Thunemann M, Hofmann F, Schuler B, Vogel J, Pichler B, Kasinathan RS, Nicolay JP, Huber SM, Lang F, Feil R: Anemia and splenomegaly in cGKI-deficient mice. Proc Natl Acad Sci USA 2008;105:6771-6776.

39 Foller M, Mahmud H, Gu S, Wang K, Floride E, Kucherenko Y, Luik S, Laufer S, Lang F: Participation of leukotriene C(4) in the regulation of suicidal erythrocyte death. J Physiol Pharmacol 2009;60:135-143.

40 Lau IP, Chen H, Wang J, Ong HC, Leung KC, Ho HP, Kong SK: In vitro effect of CTAB- and PEG-coated gold nanorods on the induction of eryptosis/erythroptosis in human erythrocytes. Nanotoxicology 2012;6:847856.

41 Maellaro E, Leoncini S, Moretti D, Del Bello B, Tanganelli I, De Felice C, Ciccoli L: Erythrocyte caspase-3 activation and oxidative imbalance in erythrocytes and in plasma of type 2 diabetic patients. Acta Diabetol 2013;50:489-495.

-42 Kucherenko Y, Zelenak C, Eberhard M, Qadri SM, Lang F: Effect of casein kinase 1alpha activator pyrvinium pamoate on erythrocyte ion channels. Cell Physiol Biochem 2012;30:407-417.

43 Zelenak C, Eberhard M, Jilani K, Qadri SM, Macek B, Lang F: Protein kinase CK1alpha regulates erythrocyte survival. Cell Physiol Biochem 2012;29:171-180.

44 Bhavsar SK, Gu S, Bobbala D, Lang F: Janus kinase 3 is expressed in erythrocytes, phosphorylated upon energy depletion and involved in the regulation of suicidal erythrocyte death. Cell Physiol Biochem 2011;27:547-556.

45 Klarl BA, Lang PA, Kempe DS, Niemoeller OM, Akel A, Sobiesiak M, Eisele K, Podolski M, Huber SM, Wieder T, Lang F: Protein kinase C mediates erythrocyte "programmed cell death" following glucose depletion. Am J Physiol Cell Physiol 2006;290:C244-C253.

46 Gatidis S, Zelenak C, Fajol A, Lang E, Jilani K, Michael D, Qadri SM, Lang F: p38 MAPK activation and function following osmotic shock of erythrocytes. Cell Physiol Biochem 2011;28:1279-1286.

47 Foller M, Sopjani M, Koka S, Gu S, Mahmud H, Wang K, Floride E, Schleicher E, Schulz E, Munzel T, Lang F: Regulation of erythrocyte survival by AMP-activated protein kinase. FASEB J 2009;23:1072-1080.

48 Zelenak C, Foller M, Velic A, Krug K, Qadri SM, Viollet B, Lang F, Macek B: Proteome analysis of erythrocytes lacking AMP-activated protein kinase reveals a role of PAK2 kinase in eryptosis. J Proteome Res 2011;10:1690-1697.

49 Lupescu A, Jilani K, Zelenak C, Zbidah M, Qadri SM, Lang F: Hexavalent chromium-induced erythrocyte membrane phospholipid asymmetry. Biometals 2012;25:309-318.

50 Shaik N, Lupescu A, Lang F: Sunitinib-sensitive suicidal erythrocyte death. Cell Physiol Biochem 2012;30:512-522.

51 LaRocca TJ, Stivison EA, Hod EA, Spitalnik SL, Cowan PJ, Randis TM, Ratner AJ: Human-specific bacterial pore-forming toxins induce programmed necrosis in erythrocytes. MBio 2014;5:e01251-01214.

52 Zhang R, Xiang Y, Ran Q, Deng X, Xiao Y, Xiang L, Li Z: Involvement of calcium, reactive oxygen species, and ATP in hexavalent chromium-induced damage in red blood cells. Cell Physiol Biochem 2014;34:1780-1791.

53 Arnold M, Bissinger R, Lang F: Mitoxantrone-induced suicidal erythrocyte death. Cell Physiol Biochem 2014;34:1756-1767.

54 Firat U, Kaya S, Cim A, Buyukbayram H, Gokalp O, Dal MS, Tamer MN: Increased caspase-3 immunoreactivity of erythrocytes in STZ diabetic rats. Exp Diabetes Res 2012;2012:316384.

55 Ganesan S, Chaurasiya ND, Sahu R, Walker LA, Tekwani BL: Understanding the mechanisms for metabolism-linked hemolytic toxicity of primaquine against glucose 6-phosphate dehydrogenase deficient 
Faggio/Alzoubi/Calabrò/Lang: PRIMA-1-Induced Eryptosis

human erythrocytes: evaluation of eryptotic pathway. Toxicology 2012;294:54-60.

56 Bissinger R, Lupescu A, Zelenak C, Jilani K, Lang F: Stimulation of eryptosis by cryptotanshinone. Cell Physiol Biochem 2014;34:432-442.

57 Jilani K, Qadri SM, Lang F: Geldanamycin-induced phosphatidylserine translocation in the erythrocyte membrane. Cell Physiol Biochem 2013;32:1600-1609.

58 Zbidah M, Lupescu A, Jilani K, Lang F: Stimulation of suicidal erythrocyte death by fumagillin. Basic Clin Pharmacol Toxicol 2013;112:346-351.

59 Lupescu A, Bissinger R, Warsi J, Jilani K, Lang F: Stimulation of erythrocyte cell membrane scrambling by gedunin. Cell Physiol Biochem 2014;33:1838-1848.

60 Jacobi J, Lang E, Bissinger R, Frauenfeld L, Modicano P, Faggio C, Abed M, Lang F: Stimulation of erythrocyte cell membrane scrambling by mitotane. Cell Physiol Biochem. 2014;33:1516-1526.

61 Lupescu A, Bissinger R, Herrmann T, Oswald G, Jilani K, Lang F: Induction of suicidal erythrocyte death by novobiocin. Cell Physiol Biochem 2014;33:670-680.

62 Polak-Jonkisz D, Purzyc L: Ca Influx versus Efflux during Eryptosis in Uremic Erythrocytes. Blood Purif 2012;34:209-210.

-63 Qian EW, Ge DT, Kong SK: Salidroside protects human erythrocytes against hydrogen peroxide-induced apoptosis. J Nat Prod 2012;75:531-537.

-64 Bissinger R, Modicano P, Frauenfeld L, Lang E, Jacobi J, Faggio C, Lang F: Estramustine-induced suicidal erythrocyte death. Cell Physiol Biochem 2013;32:1426-1436.

-65 Vota DM, Maltaneri RE, Wenker SD, Nesse AB, Vittori DC: Differential erythropoietin action upon cells induced to eryptosis by different agents. Cell Biochem Biophys 2013;65:145-157.

66 Weiss E, Cytlak UM, Rees DC, Osei A, Gibson JS: Deoxygenation-induced and Ca(2+) dependent phosphatidylserine externalisation in red blood cells from normal individuals and sickle cell patients. Cell Calcium 2012;51:51-56.

67 Zappulla D: Environmental stress, erythrocyte dysfunctions, inflammation, and the metabolic syndrome: adaptations to CO2 increases? J Cardiometab Syndr 2008;3:30-34.

68 Abed M, Herrmann T, Alzoubi K, Pakladok T, Lang F: Tannic acid induced suicidal erythrocyte death. Cell Physiol Biochem 2013;32:1106-1116.

69 Malik A, Bissinger R, Calabrò S, Faggio C, Jilani K, Lang F: Aristolochic Acid Induced Suicidal Erythrocyte Death. Kidney Blood Press Res 2014;39:408-419.

70 Abed M, Zoubi KA, Theurer M, Lang F: Effect of dermaseptin on erythrocytes. Basic Clin Pharmacol Toxicol 2013;113:347-352.

71 Ahmed MS, Langer H, Abed M, Voelkl J, Lang F: The uremic toxin acrolein promotes suicidal erythrocyte death. Kidney Blood Press Res 2013;37:158-167.

72 Ghashghaeinia M, Cluitmans JC, Toulany M, Saki M, Koberle M, Lang E, Dreischer P, Biedermann T, Duszenko M, Lang F, Bosman GJ, Wieder T: Age Sensitivity of NFkappaB Abundance and Programmed Cell Death in Erythrocytes Induced by NFkappaB Inhibitors. Cell Physiol Biochem 2013;32:801-813.

-73 Abed M, Feger M, Alzoubi K, Pakladok T, Frauenfeld L, Geiger C, Towhid ST, Lang F: Sensitization of erythrocytes to suicidal erythrocyte death following water deprivation. Kidney Blood Press Res 2013;37:567-578.

74 Alzoubi K, Honisch S, Abed M, Lang F: Triggering of Suicidal Erythrocyte Death by Penta-O-galloyl-beta-dglucose. Toxins (Basel) 2014;6:54-65.

75 Jilani K, Lang F: Carmustine-induced phosphatidylserine translocation in the erythrocyte membrane. Toxins (Basel) 2013;5:703-716.

76 Jilani K, Enkel S, Bissinger R, Almilaji A, Abed M, Lang F: Fluoxetine induced suicidal erythrocyte death. Toxins (Basel) 2013;5:1230-1243.

77 Lupescu A, Bissinger R, Jilani K, Lang F: Triggering of suicidal erythrocyte death by celecoxib. Toxins (Basel) 2013;5:1543-1554.

78 Lupescu A, Jilani K, Zbidah M, Lang F: Patulin-induced suicidal erythrocyte death. Cell Physiol Biochem 2013;32:291-299.

79 Arnold M, Lang E, Modicano P, Bissinger R, Faggio C, Abed M, Lang F: Effect of nitazoxanide on erythrocytes. Basic Clin Pharmacol Toxicol 2014;114:421-426.

-80 Oswald G, Alzoubi K, Abed M, Lang F: Stimulation of suicidal erythrocyte death by ribavirin. Basic Clin Pharmacol Toxicol 2014;114:311-317. 
Faggio/Alzoubi/Calabrò/Lang: PRIMA-1-Induced Eryptosis

81 Bissinger R, Malik A, Jilani K, Lang F: Triggering of Erythrocyte Cell Membrane Scrambling by Salinomycin. Basic Clin Pharmacol Toxicol 2014;10.1111/bcpt.12250

82 Gao M, Lau PM, Kong SK: Mitochondrial toxin betulinic acid induces in vitro eryptosis in human red blood cells through membrane permeabilization. Arch Toxicol 2014;88:755-768.

83 Voelkl J, Alzoubi K, Mamar AK, Ahmed MS, Abed M, Lang F: Stimulation of suicidal erythrocyte death by increased extracellular phosphate concentrations. Kidney Blood Press Res 2013;38:42-51.

-84 Lang E, Gatidis S, Freise NF, Bock H, Kubitz R, Lauermann C, Orth HM, Klindt C, Schuier M, Keitel V, Reich M, Liu G, Schmidt S, Xu HC, Qadri SM, Herebian D, Pandyra AA, Mayatepek E, Gulbins E, Lang F, Haussinger D, Lang KS, Foller M, Lang PA: Conjugated bilirubin triggers anemia by inducing erythrocyte death. Hepatology 2014;10.1002/hep.27338

85 Duranton C, Huber S, Tanneur V, Lang K, Brand V, Sandu C, Lang F: Electrophysiological properties of the Plasmodium Falciparum-induced cation conductance of human erythrocytes. Cell Physiol Biochem 2003;13:189-198.

86 Kirk K: Membrane transport in the malaria-infected erythrocyte. Physiol Rev 2001;81:495-537.

-87 Foller M, Bobbala D, Koka S, Huber SM, Gulbins E, Lang F: Suicide for survival--death of infected erythrocytes as a host mechanism to survive malaria. Cell Physiol Biochem 2009;24:133-140.

88 Ayi K, Giribaldi G, Skorokhod A, Schwarzer E, Prendergast PT, Arese P: 16alpha-bromoepiandrosterone, an antimalarial analogue of the hormone dehydroepiandrosterone, enhances phagocytosis of ring stage parasitized erythrocytes: a novel mechanism for antimalarial activity. Antimicrob Agents Chemother 2002;46:3180-3184.

89 Ayi K, Turrini F, Piga A, Arese P: Enhanced phagocytosis of ring-parasitized mutant erythrocytes: a common mechanism that may explain protection against falciparum malaria in sickle trait and betathalassemia trait. Blood 2004;104:3364-3371.

-90 Cappadoro M, Giribaldi G, O'Brien E, Turrini F, Mannu F, Ulliers D, Simula G, Luzzatto L, Arese P: Early phagocytosis of glucose-6-phosphate dehydrogenase (G6PD)-deficient erythrocytes parasitized by Plasmodium falciparum may explain malaria protection in G6PD deficiency. Blood 1998;92:2527-2534.

-91 Koka S, Foller M, Lamprecht G, Boini KM, Lang C, Huber SM, Lang F: Iron deficiency influences the course of malaria in Plasmodium berghei infected mice. Biochem Biophys Res Commun 2007;357:608-614.

$\$ 92$ Koka S, Huber SM, Boini KM, Lang C, Foller M, Lang F: Lead decreases parasitemia and enhances survival of Plasmodium berghei-infected mice. Biochem Biophys Res Commun 2007;363:484-489.

\$93 Koka S, Lang C, Boini KM, Bobbala D, Huber SM, Lang F: Influence of chlorpromazine on eryptosis, parasitemia and survival of Plasmodium berghe infected mice. Cell Physiol Biochem 2008;22:261-268.

-94 Koka S, Lang C, Niemoeller OM, Boini KM, Nicolay JP, Huber SM, Lang F: Influence of NO synthase inhibitor L-NAME on parasitemia and survival of Plasmodium berghei infected mice. Cell Physiol Biochem 2008;21:481-488.

95 Borst O, Abed M, Alesutan I, Towhid ST, Qadri SM, Foller M, Gawaz M, Lang F: Dynamic adhesion of eryptotic erythrocytes to endothelial cells via CXCL16/SR-PSOX. Am J Physiol Cell Physiol 2012;302:C644-C651.

-96 Andrews DA, Low PS: Role of red blood cells in thrombosis. Curr Opin Hematol 1999;6:76-82.

97 Chung SM, Bae ON, Lim KM, Noh JY, Lee MY, Jung YS, Chung JH: Lysophosphatidic acid induces thrombogenic activity through phosphatidylserine exposure and procoagulant microvesicle generation in human erythrocytes. Arterioscler Thromb Vasc Biol 2007;27:414-421.

-98 Zwaal RF, Comfurius P, Bevers EM: Surface exposure of phosphatidylserine in pathological cells. Cell Mol Life Sci 2005;62:971-988.

99 Closse C, Dachary-Prigent J, Boisseau MR: Phosphatidylserine-related adhesion of human erythrocytes to vascular endothelium. Br J Haematol 1999;107:300-302.

100 Gallagher PG, Chang SH, Rettig MP, Neely JE, Hillery CA, Smith BD, Low PS: Altered erythrocyte endothelial adherence and membrane phospholipid asymmetry in hereditary hydrocytosis. Blood 2003;101:46254627.

101 Pandolfi A, Di Pietro N, Sirolli V, Giardinelli A, Di Silvestre S, Amoroso L, Di Tomo P, Capani F, Consoli A, Bonomini M: Mechanisms of uremic erythrocyte-induced adhesion of human monocytes to cultured endothelial cells. J Cell Physiol 2007;213:699-709.

102 Wood BL, Gibson DF, Tait JF: Increased erythrocyte phosphatidylserine exposure in sickle cell disease: flow-cytometric measurement and clinical associations. Blood 1996;88:1873-1880. 